\title{
GAMBARAN PSIKOSOSIAL ANAK JALANAN USIA REMAJA
}

\author{
Erna Marni, \\ Program studi keperawatan stikes hang tuah pekanbaru \\ Email: ernamarni86@gmail.com
}

\begin{abstract}
Adolescence is a period of self-actualization which includes physical, emotional, intellectual and social changes that will affect the development process of an individual . At this time individuals especially street children are at risk of experiencing behavioral disorders, delinquency and occurrence of violence, both as victims or as perpetrators of violence. This condition tends to make street children behave negatively and not obey with the rules. In addition, street children are also very vulnerable to crime and violence and even sexual exploitation such as a sexual harassment, abuse, becoming victims of human trafficking and even objects for pornography. In this situation will certainly cause psychosocial problems that will affect the relations with the environment in their life. This research aims to see the psychosocial description of street children, especially at adolescents. The type of this research is a simple description with 38 street children's in Pekanbaru City as a respondents. The results showed that most street children (55.3\%) have a positive psychosocial, It is expected that Social Service Unit in Pekanbaru will provide skills training to street children as to increase the positive psychosocial aspects of street children.

Keywords: Keywords: Psychosocial, Street Children.
\end{abstract}

\begin{abstract}
ABSTRAK
Masa remaja merupakan masa aktualisasi diri yang meliputi perubahan fisik, emosional, intelektual dan sosial yang akan mempengaruhi proses perkembangan seorang individu, Pada masa ini individu khusunya anak jalanan beresiko mengalami gangguan tingkah laku, kenakalan dan terjadinya kekerasan, baik sebagai korban atau pelaku dari tindak kekerasan. Hal ini cenderung membuat anak jalanan berperilaku negatif dan tidak mematuhi aturan. Selain itu, anak jalanan juga sangat rentan mendapatkan kejahatan dan perlakuan kekerasan bahkan eksploitasi seksual seperti pelecehan seksual, penganiayaan, menjadi korban perdagangan bahkan obyek untuk pornografi. Keadaan ini tentu saja akan menimbulkan masalah psikososial yang akan mempengaruhi hubungannya dilingkungannya.Penelitian ini bertujuan untuk melihan gambaran psikososial anak jalanan khususnya remaja. Jenis penelitian ini adalah deskripsi sederhana dengan jumlah responden penelitian 38 orang anak jalanan yang berada di kota Pekanbaru, diketahui hasil penelitan sebagian besar anak jalanan $(55,3 \%)$ memiliki psikososial positive, diharapkan untuk pihak dinas sosial kota Pekanbaru untuk memberikan pelatihan keterampilan kepada anak jalanan sehingga aspek psikososial anak jalanan dapat semakin meningkat.

Kata kunci: Psikososial, Anak Jalanan
\end{abstract}




\section{PENDAHULUAN}

Anak jalanan adalah anak yang berusia kurang dari 16 tahun yang berada dijalanan untuk hidup maupun bekerja dengan melakukan kegiatan ekonomi dijalan, seperti pedagang asongan, sol sepatu, penjual koran, mengamen, mengelap kaca mobil, menyewakan payung saat hujan dan lain sebagainya (Anonim, 2004 dalam Pramuchtia, 2009). Dalam kehidupan sehari-hari, sebagian anak jalanan hidup dijalan untuk bekerja, namun ada juga yang hanya untuk bersenang-senang.

Fenomena anak jalanan sudah berkembang lama, tetapi pada saat ini semakin menjadi perhatian dunia, seiring dengan meningkatnya jumlah anak jalanan diberbagai sudut kota besar yang sebagian besar dikarenakan krisis ekonomi yang terjadi (Pardede, 2008). Strategi bertahan hidup sangatlah penting bagi keluarga miskin, hal ini menyebabkan orang tua memanfaatkan anak untuk mengerjakan pekerjaan yang tidak memerlukan keahlian tertentu seperti pemulung, pengamen, pengemis, penjual koran dan sebagainya.(Pratiwi dan Sigit, 2015).

Data Unicef menyebutkan jumlah anak jalanan di dunia 150 juta jiwa. Rata-rata anak jalanan berusia 3 sampai 18 tahun. Pada tahun 2005 terjadi peningkatan jumlah anak jalanan di dunia sekitar 190 juta jiwa akibat populasi global tumbuh dan urbanisasi terus berlanjut, 6 dari 10 penduduk kota berusia di bawah 18 tahun. Diperkirakan jumlah anak jalanan setiap tahun akan terus meningkat (UNICEF, 2006).

Data Kementerian Sosial RI menyatakan jumlah anak jalanan mengalami peningkatan yang signifikan setiap tahunnya. Berdasarkan data dari Pusat Data dan Informasi Kesejahteraan Sosial, jumlah anak jalanan diseluruh Indonesia pada tahun 2006 sebanyak 232.894 anak, tahun 2010 sebanyak 159.230 anak, tahun 2011 sebanyak 67.607 anak dan pada tahun 2015 sebanyak 33.400 anak. Data lain dari Kementerian Sosial juga mencatat, jumlah anak jalanan 
pada tahun 2016 mencapai 4,1 juta atau meningkat secara drastis dari tahun 2015 (Direktorat Jenderal Rehabilitasi Sosial, 2016).

Dinas Sosial Kota Pekanbaru (2016), menyatakan bahwa anak jalanan di Kota Pekanbaru pada tahun 2010 tercatat 222 anak yang berada di jalanan, pada bulan april 2010 meningkat, tercatat 250 anak, dari berbagai kelurahan dan kecamatan yang ada di Pekanbaru. Pada tahun 2014, jumlah anak jalanan mengalami penurunan menjadi 122 anak, dan pada tahun 2015 kembali menurun menjadi 104 anak jalanan dengan rentang usia 11 hingga 18 tahun. Anak-anak jalanan dapat ditemui ditempattempat keramaian di Pekanbaru, yaitu tempat dimana mereka melakukan aktivitasnya. Anak jalanan di Pekanbaru tersebar di delapan Kecamatan, dan presentase terbesar terdapat di Kecamatan Tampan $(39,70 \%)$ atau sekitar 41 orang, menyusul Rumbai dan Pekanbaru Kota, masing-masing $15,41 \%$ (sekitar 16 orang) dan $12,16 \%$ (sekitar 12 orang) (DinSos Kota Pekanbaru, 2016).
Pada umumnya, anak jalanan berumur dibawah 18 tahun adalah anak-anak yang memiliki hak untuk memperoleh penghidupan yang layak. Menurut Hurlock, anak dalam usia 12-18 tahun adalah anak-anak yang disebut remaja. Pada periode ini perkembangan sosial anak remaja ditandai oleh usaha anak yang ingin memisahkan diri dari orang tua untuk menentukan dirinya atau mencari identitas ego, sehingga memerlukan bimbingan dari orang-orang dewasa dan lingkungan sekitarnya (Hurlock, n.d).

Masa remaja merupakan masa aktualisasi diri yang meliputi perubahan fisik, emosional, intelektual dan sosial yang akan mempengaruhi awal dan akhir masa remajanya (Rudolph, 2006). Pada masa ini mereka beresiko mengalami gangguan tingkah laku, kenakalan dan terjadinya kekerasan, baik sebagai korban atau pelaku dari tindak kekerasan (Wong, 2008). Hal ini cenderung membuat mereka berperilaku negatif dan tidak mematuhi aturan. Selain itu, anak jalanan juga sangat 
rentan mendapatkan kejahatan dan perlakuan kekerasan bahkan eksploitasi seksual seperti pelecehan seksual, penganiayaan, menjadi korban perdagangan bahkan obyek untuk pornografi (Munir, 2012). Keadaan ini tentu saja akan menimbulkan masalah psikososial yang akan mempengaruhi hubungannya dilingkungannya.

Berdasarkan penelitian

Sakalasastra (2012), menyebutkan bahwa psikososial pada anak jalanan digambarkan dalam dimensi afeksi, kognisi, psikomotor dan sosial yang cenderung negatif, seperti perasaan benci dan menyimpan dendam. Penilaian yang cenderung negatif pada dirinya dan kehidupan yang dijalaninya hingga mengkonsumsi obat-obatan terlarang hingga konsumsi minuman beralkohol. Sejalan dengan penelitian Wulansari dan Astuti (2011), dimana aspek psikososial anak jalanan memiliki mekanisme koping maladaptif, dimana cara anak jalanan mengatasi masalahnya dengan memakai NAPZA ,minum alkohol dan lainnya.

Setiap anak mempunyai tahapan perkembangan psikososial yang berbeda-beda tergantung dari usia dan juga kondisi lingkungan anak tersebut. Dari beberapa fenomena yang terdapat dalam latar belakang diatas, maka peneliti tertarik ingin mengetahui seperti apa "gambaran psikososial anak jalanan usia remaja di kota Pekanbaru”.

\section{METODE PENELITIAN}

Penelitian ini merupakan penelitian kuantitatif dengan desain penelitian deskriptif sederhana dimana suatu penelitian yang bersifat menggambarkan sebuah fenomena yang menjadi tujuan penelitian (Notoatmodjo, 2012). Tujuan dari penelitian ini menganalisa gambaran psikososial anak jalanan usia remaja di Kota Pekanbaru. Pengambiulan sampel dilakukan di tempat anak jalanan beraktivitas, lampu merah dan perempatan jalan serta terminal bus kota. Yang berjumlah 104 orang anak. Terknik pengambilan sampel dengan accidental sampling dimana peneliti dimana pengambilan sampel 
sesaui deangan kriteria yang telah ditetapkan yang ada pada saat peneliti melakuakn penelitian sebanyak 38 orang. Pengambilan sampel menggunakan kueisioner dengan julah pertanyan sebanyak 34 butir dengan memeperhatikan hak pasien dan aspek etik dalam

\section{HASIL DAN PEMBAHASAN}

Penelitian ini menggunakan analisa univariat untuk mengetahui deskripsi variabel yang diteliti yakni untuk mengetahui gambaran psikososial anak jalanan di Kota Pekanbaru.

\section{Distribusi frekuensi karakteristik} responden

Tabel 1

Distribusi frekuensi data demografi anak jalanan berdasarkan Jenis kelamin, suku, usia, pendidikan dan lama dijalanan di Kota Pekanbaru

\begin{tabular}{cccc}
\hline Data Demografi & & $\mathrm{f}$ & $\%$ \\
\hline Jenis kelamin & Laki-laki & 23 & 60,5 \\
& Perempuan & 15 & 39,5 \\
\hline & Total & 38 & $100 \%$ \\
\hline Suku & Minang & 24 & 63,2 \\
& Melayu & 2 & 5,3 \\
& Batak & 7 & 18,4 \\
& Nias & 2 & 5,3 \\
& Jambak & 1 & 2,6 \\
& Aceh & 2 & 5,3 \\
\hline \multirow{2}{*}{ Usia } & Total & 38 & $100 \%$ \\
& & & 76,3 \\
& $12-15$ tahun & 29 & 21,1 \\
& $16-18$ tahun & 8 & 2,6 \\
\hline Pendidikan & Total & 1 & $100 \%$ \\
& & 38 & 44,7 \\
& SD & & 23,7 \\
& SMP & 17 & 7,9 \\
\hline & SMA & 9 &
\end{tabular}




\begin{tabular}{lccc}
\hline & Tidak Sekolah & 9 & 23,7 \\
\hline Tama dijalanan & Total & 38 & $100 \%$ \\
& 0,5 tahun & 1 & 2,6 \\
1 tahun & 4 & 10,5 \\
1,5 tahun & 2 & 5,3 \\
2 tahun & 2 & 5,3 \\
3 tahun & 8 & 21,1 \\
4 tahun & 6 & 15,8 \\
5 tahun & 7 & 18,4 \\
6 tahun & 4 & 10,5 \\
7 tahun & 1 & 2,6 \\
8 tahun & 2 & 5,3 \\
9 tahun & 1 & 2,6 \\
\hline Total & 38 & $100 \%$ \\
\hline
\end{tabular}

Berdasarkan tabel 1 diatas dapat sebanyak 29 orang (76,3\%). dilihat bahwa mayoritas anak jalanan Mayoritas anak jalanan di Kota di Kota Pekanbaru berjenis kelamin Pekanbaru masih duduk dibangku laki-laki sebanyak 23 orang $(60,5 \%)$. sekolah dasar/ SD sebanyak 17 orang Mayoritas anak jalanan di Kota (44,7\%). Mayoritas anak jalanan di Pekanbaru bersuku bangsa minang Kota Pekanbaru yang telah berada sebanyak 24 orang $(63,2 \%)$ dijalanan selama 3 tahun sebanyak 8 Mayoritas anak jalanan di Kota orang $(21,1 \%)$.

Pekanbaru berusia 12-15 tahun

\section{Distribusi frekuensi psikososial}

Tabel 2

Distribusi frekuensi psikososial di Kota Pekanbaru Tahun 2017

\begin{tabular}{ccc}
\hline Variabel & F & $\%$ \\
\hline Psikososial & & \\
Positif & 21 & 55,3 \\
Negatif & 17 & 44,7 \\
\hline Total & 38 & $100 \%$ \\
\hline
\end{tabular}


Berdasarkan tabel 2 diatas dapat dilihat bahwa mayoritas anak jalanan di Kota Pekanbaru memiliki

\section{Pembahasan}

Hasil penelitian menunjukkan bahwa sebagian besar anak jalanan memiliki psikososial positif yaitu sebanyak 55,3\%. Psikososial adalah istilah yang digunakan dalam menggambarkan hubungan antara kondisi sosial seseorang dengan kesehatan mental atau emosional dengan arti kata lain psikososial melibatkan aspek psikologis dan sosial seperti hubungan antara kekuatan yang dimiliki seseorang terhadap bagaimana cara individu tersebut berinteraksi dengan orang lain. Diketahui seseorang memiliki kesehatan mental yang baik maka akan bereaksi secara positif dalam berbagai situasi demikian sebaliknya individu yang tidak stabil mentalnya secara otomatis akan bereaksi negatif terhadap sesuatu yang dialaminya didalam hidup.

Masa remaja merupakan masa aktualisasi diri yang meliputi perubahan fisik, emosional, intelektual dan sosial yang akan psikososial positif sebanyak 21 orang $(60,5 \%)$.

mempengaruhi awal dan akhir masa remajanya (Rudolph, 2006). Pada masa ini seseorang beresiko mengalami gangguan tingkah laku, kenakalan dan terjadinya kekerasan, baik sebagai korban atau pelaku dari tindak kekerasan (Wong, 2008). Hal ini cenderung membuat mereka berperilaku negatif dan tidak mematuhi aturan. Selain itu, anak jalanan juga sangat rentan mendapatkan kejahatan dan perlakuan kekerasan bahkan eksploitasi seksual seperti pelecehan seksual, penganiayaan, menjadi korban perdagangan bahkan obyek untuk pornografi (Munir, 2012). Keadaan ini tentu saja akan menimbulkan masalah psikososial yang akan mempengaruhi hubungannya dilingkungannya.

Berdasarkan penelitian Sakalasastra (2012), menyebutkan bahwa psikososial pada anak jalanan digambarkan dalam dimensi afeksi, kognisi, psikomotor dan sosial yang cenderung negatif, seperti perasaan benci dan menyimpan dendam. 
Penilaian yang cenderung negatif pada dirinya dan kehidupan yang dijalaninya hingga mengkonsumsi obat-obatan terlarang hingga konsumsi minuman beralkohol.

Hasil penelitian ini menujukkan bahwa sebagain besar anak jalanan memilki gambaran psikososial yang positif dimana anak jalanan memiliki kesehatan mental yang baik serta dapat dapat bereaksi dengan cara yang positif terhadap lingkungannya, penelitian ini tidak didukung oleh penelitian yang dilakukan oleh Wulansari dan Astuti (2011), dimana aspek psikososial anak jalanan memiliki mekanisme koping maladaptif, cara anak jalanan mengatasi masalahnya dengan memakai NAPZA ,minum alkohol dan lainnya.

Penelitian ini menunjukkan bahwa anak jalanan juga berpeluang memiliki perkembangan psikososial yang positif hal ini dapat dipengaruhi oleh motivasi internal dari individu tersebut dimana sebagian besar anak jalanan melakukan kegiatan dijalanan untuk mendapatkan tambahan pengahasilan ekonomi dalam rangka membantu ekonomi keluarga, sehingga secara tidak langsung memberikan dampak positiv, meningkatkan kepercayaan diri, dan meningkatkan aktualisasi diri hal ini membuat dirinya merasa berguna dan berarti bagi kelangsungan perekonomian keluarga.

\section{KESIMPULAN}

Mayoritas anak jalanan di Kota Pekanbaru berjenis kelamin laki-laki sebanyak 23 orang $(60,5 \%)$, bersuku bangsa minang $(63,2 \%)$, dengan rentang usia berusia 12-15 tahun sebanyak (76,3\%). Sebagian besar telah berada dijalanan selama 3 tahun sebanyak $(21,1 \%)$. Sebagian besar anak jalanan memilki psikososial positif $(55,3 \%)$

\section{DAFTAR PUSTAKA}

Ali, M., \&Asrori, M. (2011). Psikologi remaja perkembangan peserta didik. Jakarta: Bumi Aksara

Bajari, A. (2012). Anak jalanan dinamika komunikasi dan perilaku sosial anak menyimpang. Bandung: Humaniora 
Deswita. (2006). Psikologi perkembangan. Bandung: Remaja Rosdakarya

Dinas Sosial Kota Pekanbaru. (2016).Data anak jalanan Kota Pekanbaru 2015

Direktorat Jenderal Rehabilitasi Sosial. (2016). Bebas anjal tahun 2017. Diakses tanggal 12 November 2016 dari https://rehsos.kemsos.go.id/modul $\underline{\text { es.php? } \text { name }=\text { News \& file }=\text { article }}$ $\&$ sid $=1945$

Fadila \& Hartini. (2017). Konsep diri anak jalanan di Kabupaten Rejang Lebong. Jurnal Fokus Konseling. Vol. 3

Muslim, A. (2013). Faktor dominan anak turun kejalan. Diperoleh dari http://jurnal.usu.ac.id/index.php/w s/article/download/2125/1168

Nasution, M. (2007). Harga diri anak jalanan. Jurnal ilmiah berkala psikologi. Vol. 9

Notoatmodjo. (2012). Metodologi penelitian kesehatan (ed. Rev). Jakarta: Rineka Cipta

Nurihsan, J., \& Agustin. (2011).Dinamika perkembangan anak \& remaja. Bandung: Refika Aditama
Pardede, Y. O. K. (2008). Konsep diri anak jalanan usia remaja. Jurnal Psikologi, (2), 147 dan 151 Persada, RM., K., B. (2012). Kekerasan personal terhadap anak jalanan sebagai individu dalam ruang publik. Diperoleh dari http://lib.ui.ac.id/file?file=digital/ 20314990-S-

RM\%20Ksatria\%20Bhumi\%20Pe $\underline{\text { rsada.pdf }}$

Pramuchtia, Y dan Nurmala,K. P. (2010). Konsep diri anak jalanan. Jurnal transdisiplin sosiologi, komunikasi dan ekologi manusia, 255-275

Pratiwi, W., P dan Sigit, N. (2015). Social adjustment on street children. An- Nafs, (9). 69. Diperoleh dari http://jurnal.uir.ac.id/index.php/J $\underline{\text { AN/article/view/398/337 }}$

Rudolph. (2006). Buku ajar pediatric. Jakarta: EGC

Sarwono, S., W. (2010). Psikologi remaja. Jakarta: PT Raja Grafindo Persada

Unayah, N., \& Subarisman, M. (2015). Fenomena kenakalan remaja dan kriminalitas. Sosio informa (1) 121-140 
UNICEF. (2008). Diperoleh dari http://www.unicef.org/sowc06/pro files/street.php. Diakses tanggal 9 November 2015

Wong. (2009). Buku ajar keperawatan pediatrik. Jakarta:EGC

Yusuf. (2011). Psikologi perkembangan anak dan remaja. Bandung: remaja Rosdakarya 